\title{
Cutaneus cancers in elderly Medical treatment of actinic keratosis and superficial coutaneus cancers: imiquimod
}

\author{
M N Dastoli \\ From de Senectute: Age and Health Forum \\ Catanzaro, Italy. 5-7 December 2009
}

\section{Background}

The aim of this work is to evaluate the efficacy and safety of imiquimod $5 \%$ cream used in the treatment of certain non-melanoma skin cancers.

\section{Materials and methods}

We treated 30 subjects: 5 actinic keratosis, 3 cheratoacanthomas, 5 cutaneous horns, 5 superficial basal cell carcinomas, 12 nodular basal cell carcinomas according to the therapeutic pattern - five applications a week for 6-12 weeks. The patients with nodular forms could not be treated with surgery for severe chronic deseases, age, or refusal.

\section{Results}

Imiquimod 5\% cream was effective and well tolerated both in actinic keratosis and in superficial and nodular basal cell carcinoma.

\section{Conclusions}

The treatment of certain non-melanoma coutaneous toumors with imiquimod $5 \%$ cream, has been effective, without collateral effects; erythema, edema, vesicles, crusts and erosions with itching or burning in the application area, have been the most frequent adverse events which however did not cause the suspension of therapy.

A diligent and continuative follow-up is necessary.

ASP Cosenza, Corigliano Calabro, Italy
Published: 19 May 2010

doi:10.1186/1471-2318-10-S1-A92

Cite this article as: Dastoli: Cutaneus cancers in elderly Medical treatment of actinic keratosis and superficial coutaneus cancers: imiquimod. BMC Geriatrics 2010 10(Suppl 1):A92.

Submit your next manuscript to BioMed Central and take full advantage of:

- Convenient online submission

- Thorough peer review

- No space constraints or color figure charges

- Immediate publication on acceptance

- Inclusion in PubMed, CAS, Scopus and Google Scholar

- Research which is freely available for redistribution 